\title{
The importance of interpretation of normative legal acts in the process of law enforcement
}

\section{Shakhzod SAYDULLAEV ${ }^{1}$}

Tashkent State University of Law

\section{ARTICLE INFO}

\section{Article history:}

Received September 2020

Received in revised form

15 September 2020

Accepted 15 October 2020

Available online

30 October 2020

Keywords:
normative legal acts
legislative acts
law enforcement
legal norm
interpretation
explanation.

\begin{abstract}
The article covers the concept, essence and principles of interpretation of normative legal acts. There is a scientific discussion on the views of a number of scientists. During the discussion, issues related to the correct understanding and interpretation of the content of legal norms, their application to social relations were considered. Methods of interpretation of normative legal acts are explained. At the same time, special attention was paid to the subjects, types of interpretation of legal norms, the factors leading to the ambiguity of some norms in the normative legal acts, gaps in the law were studied in depth, and developed proposals for their effective elimination. In addition, a comparative analysis of national and foreign experience in the interpretation of normative legal documents was carried out, showing the peculiarities of different legal families. At the end of the article, the author puts forward appropriate proposals for amendments and additions to the interpretation of normative legal acts of the Republic of Uzbekistan, aimed at improving the existing legislation.
\end{abstract}

2181-1415/C) 2020 in Science LLC.

This is an open access article under the Attribution 4.0 International (CC BY 4.0) license (https://creativecommons.org/licenses/by/4.0/deed.ru)

\section{Хуқуқни қўллаш жараёнида норматив-хуқуқий хужжатларни шархлашнинг ахамияти}

\author{
Калит сўзлар: \\ норматив-хуқуқий \\ хужжатлар \\ қонун хужжатлари \\ хуқуқни қўллаш \\ шархлаш
}

АННОТАЦИЯ

Мақолада норматив-хуқуқий хужжатларни шархлаш тушунчаси, мохияти ва унинг принциплари хақида сўз юритилган.Бу борада қатор олимларнинг қарашлари юзасидан илмий мухокамага киришилган. Мухокама жараёнида хуқуқ нормаларининг мазмунини тўғри англаб

\footnotetext{
${ }^{1}$ DSc, professor, Dean of the Faculty of Public Law of Tashkent State University of Law, Tashkent, Uzbekistan email: sh.saydullaev@tsul.uz
} 
хукуқ нормаси интерпретация тушунтириш олиш ва уларни шархлаш, ижтимоий муносабатларга уларни қўллашга оид масалалар кўриб чиқилган. Нормативхукуқий хужжатларни шархлаш усулларикўрсатиб берилган. Бунда хуқуқ нормаларини шархлашнинг субъектлари, турларига алохида тўхталиб, нормативхуқуқий хужжатлардаги айрим нормаларнинг ноаниқлигига, хуқуқдаги бўшлиқларга олиб келувчи омиллар чуқур тадқиқ этилиб, уларни самарали бартараф этишга қаратилган таклифлар ишлаб чиқилган. Шунингдек, норматив-хуқуқий хужжатларни шархлашда миллий ва хорижий тажриба ўзаро қиёсий тахлил қилиниб, турли хуқуқ оилаларидаги ўзига хос жихатлар кўрсатилган.Мақола сўнггида муаллиф томонидан амалдаги қонунчиликни такомиллаштиришга қаратилган Ўзбекистон Республикасининг норматив-хуқуқий хужжатларини шархлаш билан боғлиқ тегишли ўзгартиш ва қўшимчалар киритиш бўйича тегишли таклифлар илгари сурилган

\section{Значение толкования нормативно-правовых актов в процессе правоприменения}

\author{
Ключевые слова: \\ Нормативно-правовые \\ документы \\ Законодательство \\ Правоохранительные \\ органы \\ Толкование \\ Правовая норма \\ Интерпретация \\ Разъяснение
}

\section{АННОТАЦИЯ}

В статье раскрыто понятие, сущность и принципы толкования нормативно-правовых актов. Проводится научное обсуждение взглядов ряда ученых. В ходе дискуссии были рассмотрены вопросы, связанные с правильным пониманием и толкованием содержания правовых норм, их применением к общественным отношениям. Разъясняются способы толкования нормативно-правовых актов. При этом особое внимание было уделено тематике, типам толкования норм права, факторам, приводящим к неоднозначности некоторых норм в нормативно-правовых актах, были детально изучены пробелы в законодательстве, разработаны предложения по их действию, устранению. Кроме того, проведен сравнительный анализ отечественного и зарубежного опыта толкования нормативно-правовых документов, показывающий особенности различных правовых семейств. В конце статьи автор выдвигает соответствующие предложения по внесению изменений и дополнений в действующее законодательство, направленных на совершенствование толкования нормативно-правовых актов Республики Узбекистан. 


\section{INTRODUCTION}

The issue of interpretation of normative legal acts is one of the urgent issues of the modern jurisprudence. Interpretation of normative legal acts as a special legal category has its own content and essence. In the law enforcement, its general description is determined, applicable to certain life circumstances. In order to properly implement and apply normative legal acts in practice, it is necessary to interpret them.As a result, the content of the social relations used in the text is consistent with the expression of legal norms.

Read the statute; (I) read the statute; (II) read the statute!"(III) Great judges tell these are the fundamental rules of statutory interpretation [i]. Their admonition reflects a standard picture of the interpretive process. People often assume, usually without realizing it, that a judge's job is to "read the [text] and do what it says [ii]." They may disagree violently about how the text should be read; but if only we could accurately read the authors' minds [iii], or discern their purposes [iv], or compile the ideal legal dictionary for their time and place, or whatnot, then we'd know what to do. The law the text enacts just is whatever the text says it is [v].

A clear and correct understanding and application of the content and essence of normative legal acts creates the basis for the emergence of a legal order in the country in the interests of society. Although specific problems related to the legislative process, the legal system, legal techniques have been studied to some extent in the study of the theory of law, the issues of interpretation of normative legal acts in the process of law enforcement are less studied in our national legal science. In addition, there is no consensus among researchers in defining the scientific content of normative-legal acts and legalization terms. In order for legal norms to be properly applied in practice, it will be necessary to interpret them.

"Interpretation" means in the Latin word "interpretatio". It means the interpretation of various material and intangible objects created by mankind. An example of this is the interpretation of works of art that are objects of material culture or the interpretation of the text of written sources. The term interpretation of the text of written sources is also used in the process of interpretation the law [vi].

Interpretation in law is a rational process by which we understand a text. Through interpretation, we come to know the normative message of a text. It is a process that "extracts" the legal meaning of the text from its semantic meaning [vii]. Interpreters translate the "human" language into "legal" language. They turn "static law" into "dynamic law." They carry out the legal norm into practice. Legal interpretation turns a semantic "text" into a legal norm - hence the distinction between the semantic meaning of a text and its legal (or normative) meaning.

Interpretation may also be conceptualized more expansively. For example, R. Dworkin defines law itself as an interpretive process: Legal practice is an exercise in interpretation not just when lawyers interpret acts or statutes but also generally. Propositions of law are not simply descriptive of legal history, in a straightforward way, nor are they simply evaluative in some way divorced from legal history. They are interpretive of legal history, which combines elements of both description and evaluation, but is different from both [viii].

Moreover, interpretation isn't just a matter of language; it's also governed by law. This "law of interpretation" determines what a particular instrument "means" in our legal 
system. Whether the written text actually has that meaning in any natural language, whether English, Latin, or legalese, is largely beside the point. The law says it does, and that's what matters [ix].

The crucial question for legal interpreters isn't "what do these words mean," but something broader: What law did this instrument make? How does it fit into the rest of the corpus juris? What do "the legal sources and authorities, taken all together, establish"? [x] Questions like these presuppose some particular system of law, and their answers depend on the other legal norms in place. Language will, of course, be an input to the process, but law begins and ends the inquiry. So, contrary to the standard view, an instrument's legal effect doesn't just follow from the meaning of its language, according to your favourite set of linguistic conventions. What to read, and what linguistic conventions to use, is itself a question of law [xi].

\section{DISCUSSION}

The implementation of the law is a multifaceted process, which manifests itself in certain forms. Law enforcement is the most important form of application of law. Therefore, it is important to comprehensively study the problems of law enforcement and interpretation and to gain a deeper understanding of its content. It should be noted that the issue of enforcement and interpretation of legal norm is one of the most pressing topics of modern jurisprudence.

Interpretation is of paramount importance in the process of applying normative legal acts and their implementation in other forms. An important aspect in the process of interpreting the law is the text of particular norm. Because it is the will of not only the legislature, but also the state, which is objectively enshrined in the normative legal acts.

Interpretation of normative legal acts depends on the level of legal consciousness, professional skills and culture of the persons carrying out this activity. In this regard, the interpretation of a particular piece of legislation may vary depending on who, how, and for what purpose. In this case, the subjective factor is more important. This is because the subjects of interpretation have different political, moral, and legal consciousness, and in some cases, they have conflicting ideological views. This, in turn, has a certain negative impact on the understanding and interpretation of law, and then leads to conflicts between the legislation and the social reality it regulates. In particular, this situation is due to the use of vague and ambiguous terms and concepts in legal acts.

If we take into account that normative-legal acts regulate the most important relations that arise in social reality, in our opinion, all legal norms should be interpreted, at least informally. This, in turn, serves as an important factor in the correct understanding and enforcement of the content and essence of the legal norm and the prevention of conflictual situations. It should be noted that it is not always possible to achieve full harmony between the spirit of the legal norms reflected in the normative legal acts and the method and form of its expression. The resolution of conflicts arising in such cases is carried out mainly through the method of interpretation.

A unified system of normative-legal acts should be formed.It is not advisable to have conflicts between them. But in practice, it is not always possible to achieve structure. In this case, the presence of collisions is natural. Because of this, conflicts in the law enforcement process can be overcome through the interpretation of legislation. 
The need to interpret the normative-legal act also arises from the possible contradictions between its form and content. Indeed, the content of the law is reflected in the normative legal acts, but, unfortunately, these acts do not always express the will of the legislature.

The low level of legal technique, deficiencies and shortcomings in the technical direction lead to gaps in the law, inconsistencies, violations of its content. In such cases, interpretation remains an important means of knowing the true content of the legal instruction.

The low level of legal technique is also a factor that makes it necessary to interpret the legislation. Due to this, the development of legal technique is a requirement of the time. The country has a number of legal and technical regulations, including parliamentary, governmental and ministerial documents. However, these normative legal acts do not form a single system.As a result, today there is a need to adopt legal technical regulations governing the complex preparation of draft regulations. Of course, proper observance of the rules of legal technique prevents the emergence of various atypical situations in the enforcement of the law, which in turn does not create the need to interpret the legal norm.

When we analyse the legal literature, we see that there is a debate on whether it is necessary to interpret all legal norms or only vague norms, that is, norms that can lead to legal conflicts [xii].

Some authors consider the interpretation of normative-legal documents to mean only the definition of the content of the legal norm, while others consider the interpretation of the content of the legal norm as interpretation. Proponents of the third approach argue that the interpretation of law is both the definition and the interpretation of the content of law. One-sidedness is allowed in the first two approaches to understanding the concept of interpretation of law. In fact, the interpretation of legislation is a complex creative process, consisting of defining and interpreting the content of the law and by-laws, which is manifested in the unity of both aspects [xiii].

According to A. Melexin, the interpretation of legal norms is a complex phenomenon of intellectual and voluntary nature, aimed at understanding and explaining the content of legal norms in order to properly apply legal norms. Interpretation is an important and necessary element in legal practice [xiv].

According to M. Toper, the meaning of interpretation means understanding, and the need for interpretation arises when the meaning is not understood, including the need to interpret when the meaning is denied [xv].

Do all norms need to be interpreted, or do only vague "puzzle norms" require interpretation? This is a traditional question for science as well. Interpretation is directly proportional to the abstraction or uncertainty of the laws. It begins where abstraction begins, and as abstraction increases, so does the complexity and necessity of interpretation. "Not only ambiguities, but any law should be interpreted," said A.M.Gulaev.

In this regard, the opinion of G. Tastanbekova is also noteworthy. In particular, she noted that the interpretation of legal norms is a multifaceted, complex and formal process aimed at understanding and explaining the content of the general will of the regulator, embodied in the legal norms of lawmakers. It should be noted that it is not always possible to achieve full harmony between the spirit of the legal norms reflected in the normative legal acts and the method and form of its expression. Conflicts in such cases are resolved mainly through the method of interpretation [xvi]. 
In the large literature on legal interpretation, we find intelligent argument and sophisticated theoretical resources. But the field lacks system or structure - there is no general understanding of what constraints a theory of legal interpretation must meet or what it must accomplish in order to be successful. Theorists enter the debate from different starting points, offering a particular consideration or type of argument in favour of a preferred account. Some theorists argue from a particular conception of supremacy of law, democracy, or legitimacy. Others maintain that the study of language yields the correct method of legal interpretation.

A system of interpretation based on authorial intent produces a different meaning than a system that asks how a reasonable reader would understand the text. Each system of interpretation produces its own principles of interpretation. These principles are, in the words of Professor Hart, [xvii]secondary rules. As secondary rules, they determine the scope or range of deployment of norms extracted from the (primary) text.

Foreign experience in the interpretation of normative legal acts shows that the interpretation has its own characteristics, depending on which legal family the countries of the world belong to. In particular, in countries belong to the Anglo-Saxon family of law, the interpretation of law is not carried out by a separate body in a separate procedural order, on the contrary, these processes are interpreted and applied by the judiciary in a casual manner.

In countries belonging to the Romano-Germanic law family, the constitutional court or other bodies exercising its powers shall act as the body engaged in interpretation, and the relevant law defines the scope of subjects applying to this body. For example, in Germany, there is a need for interpretation of the law, taking into account the purpose of interpreting the law and the need for clarification, which is considered a necessary element of law enforcement, as well as the ambiguity of the legal norm [xviii].

A study of German law enforcement practice suggests that references to lawyers by judges are mainly specific to Germany, as European researchers have repeatedly stated. The methodology of interpreting modern German law is based on the work of the scientist Savini, and there are some limitations from it. For example, these situations will be related to the purpose of the interpretation and the means of interpretation. However, the interpretation of the sources of constitutional law is based on the legal doctrine of Friedrich Müller.

French legal doctrine views the process of interpretation in a narrow sense as the expression of scientific opinions in writing, which are crucial in making decisions on certain issues. Hence, the interpretation will depend on the author's particular point of view, his literary genre, style, and the nature of the legal system under consideration. French legal theory stems from the need for interpretation and the rules of legal conduct, as well as individual legal acts [xix].

When it comes to the object of interpretation activity, it should be noted that interpretation is done through two law schools. At the same time, Professor J.L. Bergel argues that according to the principle of freedom will enshrined in the Civil Code of 1804, the meaning of a legal act may be the product of the agreed will of the author of the act and the judge must limit himself to concepts derived from its purpose.

Provisions that do not require initial proof of consensus, like the basis of a contract, force the parties to understand their true views at the time act is drawn up. In order to determine what the author's will was at the time the document was drafted, it should not 
be based on problematic circumstances. Nevertheless, this concept, based on civil and classical models, is currently being adapted to the requirements of different areas of law.

In public law, on the other hand, the judge must interpret the ambiguities in the act according to their date of origin, which means that the administrative courts rely on the actual circumstances of the case.

It is clear from the cases arising from the French legal doctrine that the two main directions determined the appearance of the interpretive activity. The first method is called the subjective methods of interpretation, while the second, in contrast, is formed from the objective means of interpretive activity.

In English legal theory, it is accepted to divide the process of interpretation into two stages, i.e. interpretation and construction in the strict sense. Interpretation is a mental activity to reveal the content and meaning of a normative legal document, and construction should be understood as an activity of clarifying the ambiguities and various meanings in these documents.

Interpretation is a mental effort by a high-level commentator to clarify the content and meaning of a text, while interpretation is an activity by other individuals to clarify the situation from their own point of view.

In English, the term interpretation is considered to be the result of an activity or document aimed at determining the significance and meaning of the object of interpretation. Interpretation is used in the sense of explaining or clarifying the meaning, interpreting, translating into a comprehensible or familiar language, identifying, discussing, understanding.

Construction is a mental activity directed by the commentator towards the external environment, which is aimed at creating new situations. It should be noted that we must distinguish between general interpretation and interpretation of the scope of the relationship, casual interpretation of the enforcement of norms, which has a substantiated structure reflected in the law enforcement document and is directed to specific legal relations. The meanings of the above English terms (interpretation and construction) vary in a narrow legal understanding, and this fact has been confirmed by many researchers. Interpretation is a process aimed at determining the meanings of words in the text of the law, and this activity is used when there are uncertainty and ambiguity in the statute.

Through interpretation, doubts arising from the uncertainty and ambiguity in the text are resolved. The content of each norm is interpreted as it is considered by the court, and dubious and ambiguous cases are interpreted.

It would be wrong to view the interpretation of statutes simply as a result of the application of logical rules, from the British point of view the process of interpreting laws involves an analysis of all legal materials (law, precedent, rules, presumptions and linguistic rules) applicable to the social relations under consideration.

According to Ilbert, should be had to the general rules for the interpretation of statutes, as laid down in the ordinary textbooks [xx]. Among the most important of these are:

1. The rule that an Act must be read as a whole. Therefore, the language of one section may affect the construction of another.

2. The rule that an Act may be interpreted by reference to other Acts dealing with the same or a similar subject matter. The meaning attached to a particular expression in 
one Act, either by definition or by judicial decision, may be attached to it in another. And variation of language may be construed as indicating change of intention.

3 . The general rule that special provisions will control general provisions.

4. The similar rule that where particular words are followed by general words (horse, cow, or other animal) the generality of the latter will be limited by reference to the former ('Ejusdem Generis' rule).

5. The general rule, subject to important exceptions, that a guilty mind is an essential element in a breach of a criminal or penal law. It should, therefore, be considered whether the words 'willfully' or 'knowingly' should be inserted, and whether, if not inserted, they would be implied, unless expresely negatived.

6. The presumption that the legislature does not intend any alteration in the rules or principles of the common law beyond what it expressly declares.

7. The presumption against an intention to oust or limit the jurisdiction of the superior courts.

8. The presumption that an Act of Parliament will not have extra territorial application.

9. The presumption against any intention to contravene a rule of international law.

10. The rule that the Crown is not bound by an enactment unless specially named.

11. The presumption against the retrospective operation of a statute, subject to an exception as to enactments which affect only the practice and procedure of the courts.

12. The norm that a power conferred on a public authority may be construed as a duty imposed on that authority ('may = shall').

According to Michelle Troper, interpretation activity means to identify or demonstrate something. The first definition comes from the point of view of performing the interpretive function, and the second definition comes from the point of view of expressing a wish. Each of the given concepts corresponds to its own theory.

The doctrine of interpretation of the law helps to set the precedent right mentally as opposed to the statutory right and ensures a balance of interests between the public authorities and civil society.

Two systems - judicial practice and legislative acts - are in constant interaction. The nature of this interaction depends on the type of legal system and the type of legal consciousness of the state concerned. Anglo-American and Romano-Germanic legal systems essentially differ in assessing the interaction of judicial practice and legislation. As we know, Romano-German legal doctrine does not recognize judicial practice as the source of law, and does not classify courts as a law-making body. Anglo-American legal doctrine considers judicial precedent as a source of law and judicial interpretation as a law. These differences in legal systems are the basis for understanding the interaction between judicial and legislative powers, magisterial law and legislation. In the Anglo-American legal system, there is no reason to talk about the impact of judicial practice on lawmaking because these concepts are the same (law and precedent). In the Roman Germanic legal system, interaction of precedent and legislation is a critical issue.

It can be said that in the Anglo-Saxon legal family, the judge uses the creativity of the law to interpret the law and eliminate existing shortcomings in court proceedings, and the courts set a specific precedent. This then applies to all similar relationships.

In the Romano-Germanic legal family, the interpretation of legislation is usually done by the body that passed the law or by a specially authorized body, and is published 
in official publications. However, the question of the legal force of the document issued under the interpretation is still controversial.

The issue of interpretation of normative legal acts includes the following three important issues: 1) identification of the subject interpreting the legal norm (government agencies, officials, etc.). 2) the choice of methods used to determine the content of the legal norm (logical, grammatical, historical and systematic, etc.); 3) interpretation of the applied norm in terms of volume and legal force.

Interpretation of legal norms is carried out in a number of ways. In particular, grammatical interpretation focuses not on the general essence of the legal norm, but on the essence of the individual terms, words and phrases in it. Grammatical interpretation prevents mistakes in the use of terms in legal norms.

Logical interpretation, unlike grammatical interpretation, serves not to determine the literal meaning of words in a legal norm, but to understand the essence of a norm that lawmaker wants to express and is not expressed in a clear word form. Through logical interpretation, two different interpretations of the legal norm arise. The first of these is the essence of the law, while the second is the essence determined by logical interpretation.

Historical-political interpretation is reflected in the study of socio-economic, political aspects and historical conditions of the legal norm. This requires determining the purpose of the adoption of the normative legal act, the socio-political situation that led to its emergence, the place, time and practice of enforcement of the normative legal act. In particular, "historical and political interpretation is very important for law enforcement officers. Because this activity is linked with the interests of the state and their protection. Therefore, understanding the political purpose of the legislation, knowing its history, helps to make the work qualitative and goal-oriented [xxi].

In a systematic interpretation, the legal norm governing a particular social relationship is not limited to the scope of a specific document. Perhaps in this case, the content of all the normative legal acts regulating the relevant relationship is interpreted in context. In this regard, it should be noted that systematic interpretation is important in the enforcement of a particular norm correctly and in full compliance with the law. Therefore, the normative-legal document should be, first of all, based on logical regularity, interconnected and consist of a system of norms, each of which derives from the content of the previous norm.

In the method of systematic interpretation, the meaning and content of legal norm is determined by its place and role in the normative legal act, the legal norm, the legal institution, the field of law and the whole legal system. Systematic interpretation identifies conflicts, inconsistencies between norms and documents. As a result of such interpretation, insignificant, unused legal norms that have not been formally abolished but have in practice been replaced by others are also identified.

Through the systematic method of interpretation, the subject of the commentator firstly determines the role of legal norm in the legal system, secondly, the logical relationship between the interpreted legal norm and the specific life relationship to which this norm is applied, and thirdly, the content of the interpreted norm [xxii]. It is also determined whether the systematic method has been replaced by a new legal norm, whether there are exceptions to the rule.

In the process of systematic interpretation, the content of the sentences "in accordance with the law", "in the manner prescribed by law", "in accordance with the law", 
which occur in some laws, should also be disclosed. This is because the existence of such references indicates that the legal regulation of certain social relations has not been completed and that the norms of this reference have no legal significance. This creates difficulties in the correct enforcement and interpretation of the legal norm in social relations. Therefore, it is advisable that the legislation should provide clear, strict and complete rules.

There are also several theories of interpretation, which are as follows:

Intentionalism has long been the most widely accepted theory of statutory interpretation. Blackstone opined that "the fairest and most rational method to interpret the will of the legislator, is by exploring his intentions at the time when the law was made" [xxiii].

Some of the most prominent scholars and judges influenced by public choice have eschewed intentionalism as a hopeless endeavour that inevitably leads to unconstrained judicial interpretation. They have embraced instead a second foundational theory of interpretation: textualism. Some defenders of textualism do so on formalist grounds: The Constitution sets out the exclusive mechanism for enacting policy, and ant legislative materials that have not gone through those procedural hoops cannot be given the status of legislation. That position, however, does not necessarily rule out using legislative materials that reveal the political context surrounding enactment as evidence of meaning when textual provisions are unclear. The textualist rejects even this use of legislative history for the reasons provided above: Legislative history is manipulated by strategic political actors who could not enact their preferences, and legislative materials provide clues only to the motivations of a few lawmakers, not the intent of a collective body, which itself is an inherently unintelligible concept [xxiv] .

The third foundational theory is purposivism. Interpreters should identify both the mischief that prompted Parliament's action and the remedy chosen to attack the mischief. The notion that interpreters should construe legislation so that it achieves its purpose is hardly controversial; all three foundational theories incorporate some purposive analysis. What distinguishes the theories is how the purpose is identified. For intentionalists the relevant purpose is that of the enactors; for textualists, the purpose is determined by examining the language of the statue and how it fits into the body of law. Purposivists writing in the Legal Process tradition, assume "unless the contrary unmistakably appears, that the legislature was made up of reasonable persons pursuing reasonable purposes reasonably" [xxv]. Inferring this purpose includes a close examination of text and other sources of meaning, although the process does not aim necessarily to capture the subjective intent of the enactors. Instead, purposivists create a "reasonable" legislator and determine how she might have attacked the mischief targeted by the legislature [xxvi].

The legal basis for the interpretation of legal norms is reflected in a number of legal norms. For example:

1. According to Article 43 of the Law of the Republic of Uzbekistan "On normative legal acts", "official interpretation of normative legal acts is carried out in case of inaccuracies in the normative legal act, its incorrect or contradictory application in practice. The Constitutional Court of the Republic of Uzbekistan shall provide an official interpretation of the provisions of the Constitution and laws of the Republic of Uzbekistan. Official interpretation of the norms of by-laws is provided by the bodies that adopted them. 
In the process of official interpretation of normative legal acts, it is not allowed to make corrections, changes, additions to them in order to clarify the norms." [xxvii].

2. According to Article 2 of the Constitutional Law of the Republic of Uzbekistan "On the Constitutional Court of the Republic of Uzbekistan", the Constitutional Court of the Republic of Uzbekistan is a permanent judicial body for consideration of cases on the constitutionality of legislative and executive acts.

The Constitutional Court of the Republic of Uzbekistan shall: define the compliance of the Constitution of the Republic of Uzbekistan, laws of the Republic of Uzbekistan and resolutions of the chambers of the Oliy Majlis of the Republic of Uzbekistan, decrees of the President of the Republic of Uzbekistan, enactments of the government and local bodies of state authority, interstate treaties and other obligations of the Republic of Uzbekistan; conform the compliance with the Constitution of the Republic of Karakalpakstan to the Constitution of the Republic of Uzbekistan, laws of the Republic of Karakalpakstan - to laws of the Republic of Uzbekistan; interpret the norms of the Constitution and laws of the Republic of Uzbekistan; hear other cases relating to its competence in accordance with the Constitution and laws of the Republic of Uzbekistan.[xxviii].

\section{CONCLUSION}

It should be noted that the current legislation does not have a legal framework that clearly defines the process of interpretation of normative legal acts and the legal status of interpretive documents.

The validity of multiple documents on a particular issue can lead to different interpretations, misapplication, and conflict of interest. Therefore, we consider it advisable to cover social relations, which should be regulated by laws, in a single piece of legislation.

In our opinion, it is necessary to adopt the Law "On official interpretation of the legislation of the Republic of Uzbekistan" in order to fill the gap in this area and to regulate social relations in the interpretation of legislation and increase the effectiveness of the system of correct understanding and application of legislation. The main tasks of laws are to define the basic concepts of legislation and official interpretation of legislation, the powers of the subjects of official interpretation of legislation, the procedure for official interpretation of legislation and the main requirements for their content and the legal force of documents on official interpretation of legislation. We believe that it is necessary to clearly define in the law the status of the decisions of the Plenum of the Supreme Court of the Republic of Uzbekistan as a interpretation document.

In conclusion, the qualitative and correct interpretation of legal norms, their content, clarity, correct understanding and enforcement will contribute to the emergence of a legal order in the country in the interests of society and the strengthening of the rule of law.

\section{References}

1. iHenry J. Friendly, Mr. Justice Frankfurter and the Reading of Statutes, in Benchmarks. 1967.-P.196, 202. (quoting Justice Frankfurter).

2. ii Daniel A. Farber \& Philip Frickey, Law and public choice: A critical introduction, 1991.-P.88.

3. iiiLarryA, Telepathic Law, 27 Const. Comment, 2010.-P.139. 
4. ivStephen B, Madison Lecture, Our Democratic Constitution, 77 N.Y.U. Law Review, 2002.-P.245, 266.

5. vWilliam B\& Stephen E. Sachs, "The Law of Interpretation," 130 Harvard Law Review 1079, 2017. -P.1082.

6. viАдилкариев Х.Т.,Тультеев И.Т., Н.П.Азизов и др. Теория государства и права /Под общей редакцией Х.T. Адилкариева. - Т.: Академия МВД Республики Узбекистан,2014. - C.392. (AdilkarievKh.T., TulteevI.T., N.P. Azizovandetc. Theory of state and law / Edited by Kh.T. Adilkariev. - T .: Academy of the Ministry of Internal Affairs of the Republic of Uzbekistan, 2014. - P.392.)

7. viiBennion F.A.R., Statutory InterpretationLondon, Dublin and Edinburgh: Butterworths. Third Edition -P.14. 1997.

8. viiiDworkin R, “Law as Interpretation,” 60 Texas Law Review, 1982. -P.529.

9. ixWilliam B \& Stephen E. Sachs, "The Law of Interpretation," 130 Harvard Law Review 1079, 2017. -P.1083.

10. xJohn Finnis, Introductionto Philosophy of law: Collected essays 1, 18 (2011).

11. xiWilliam B \& Stephen E. Sachs, "The Law of Interpretation," 130 Harvard Law Review 1079, 2017. -P.1082.

12. хііТеория государства и права.Матузов Н.И., Малько А.В. М.: Юристъ, 2004. 512 c. (Theoryofstateandlaw. MatuzovN.I., MalkoA.V. M .: Jurist, 2004 .- 512 p.)

13. хііі Давлат ва хуқуқ назарияси. Дарслик. проф. Х.Т.Одилқориев умумий тахрири остида. - Т.: Шарқ, 2009. -Б.423.(Theory of state and law. Textbook. Under the general editorship of prof. H.T.Odilkoriev. - T.: Sharq, 2009. -P.423.)

14. xiv Мелехин А.В. Теория государства и права: учебник. - М.: Маркет ДС корпорейшн, 2007.-С.381.

15. хvМишель Т.Проблема толкования и теория верховенства Конституции //Сравнительное конституционное обозрение.М.,2005,№4-171.

16. хvіАрзамасов Ю.Г. Проблемы доктринального толкования права Вестник РУДН, серия Юридические науки, 2016. -№ 4.

17. xvii Hart H.L.A. The Concept of Law. 3rd edition. - Oxford: Oxford university press, 2012.- P.94.

18. xviii Luttermann Karin. Ubersetzen juristisher Texte als ArbeiKlt'li» der Rechtslinguistik // tie Groot, Gerard-Rene; Schulze, Reiner ft" Recht und Ubersetzen. Baden-Baden: Nomos, 1999. -P. 47.

19. хххБержельЖ.Л. Общая теория права. М., 2000. -С. 420.

20. xx Ilbert, The Mechanics of Law Making, Columbia University Press, 1914. -P.120.

21. ххіСаидов А., Тожихонов У. Давлат ва хуқуқ назарияси: 2 жилд. Хуқуқ назарияси. - Т.: Адолат, 2001. - Б.227.(Saidov A., Tojixonov U. Theory of state and law: Vol 2. Theory of law. - T.: Adolat, 2001. - P.227.)

22. ххііАдилкариевХ.Т.,ТультеевИ.Т., Н.П.Азизовидр. Теория государства и права /Под общей редакцией Х.Т. Адилкариева. - Т.: Академия МВД Республики Узбекистан,2014. - C.436. (AdilkarievKh.T., TulteevI.T., N.P. Azizovandetc. Theory of state and law / Edited by Kh.T. Adilkariev. - T .: Academy of the Ministry of Internal Affairs of the Republic of Uzbekistan, 2014. - p.436.) 
23. xxii Whittington K.E., Kelemen R.D., Caldeira G.A. Law and Politics. - New York: Oxford University Press, 2008. -P.361.

24. xxiv Whittington K.E., Kelemen R.D., Caldeira G.A. Law and Politics. - New York: Oxford University Press, 2008. -P.366.

25. xxv Hart, JR., H.A., and Sacks, A.M. 1994. The Legal Process: Basic Problems in the Making and Application of Law, ed. W.N.Eskridge, JR. and P.P.Frickey. Westbury, NY: Foundation Press. -P.1378.

26. xxviWhittington K.E., Kelemen R.D., Caldeira G.A. Law and Politics. - New York: Oxford University Press, 2008. -P.370.

27. хxviі Ўзбекистон Республикаси қонун хужжатлари тўплами, 2012 й., 52-сон, 583-модда; 2014 й., 50-сон, 588-модда; 2015 й., 32-сон, 425-модда; 2016 й., 39-сон, 457-модда.(Collection of legislation of the Republic of Uzbekistan, 2012, No. 52, Article 583; 2014, No. 50, Article 588; 2015, No. 32, Article 425; 2016, No. 39, Article 457.)

28. xxviii Ўзбекистон Республикаси қонун хужжатлари тўплами, 2017 й., 22-сон, 407-модда, 37-сон, 978-модда.(Collection of legislation of the Republic of Uzbekistan, 2017, No. 22, Article 407, No. 37, Article 978.)

\section{REFERENCES}

1. Henry J. Friendly, Mr. Justice Frankfurter and the Reading of Statutes, in Benchmarks. 1967.-P.196, 202. (quoting Justice Frankfurter).

2. Daniel A. Farber \& Philip Frickey, Law and public choice: A critical introduction, 1991.-P.88.

3. LarryA, Telepathic Law, 27 Const. Comment, 2010.-P.139.

4. Stephen B, Madison Lecture, Our Democratic Constitution, 77 N.Y.U. Law Review, 2002.-P.245, 266.

5. William B\& Stephen E. Sachs, "The Law of Interpretation," 130 Harvard Law Review 1079, 2017. -P.1082.

6. AdilkarievKh.T., TulteevI.T., N.P. Azizovandetc. Theory of state and law / Edited by Kh.T. Adilkariev. - T $:$ Academy of the Ministry of Internal Affairs of the Republic of Uzbekistan, 2014. - P.392.

7. Bennion F.A.R., Statutory InterpretationLondon, Dublin and Edinburgh: Butterworths. Third Edition -P.14. 1997.

8. Dworkin R, "Law as Interpretation," 60 Texas Law Review, 1982. -P.529.

9. William B \& Stephen E. Sachs, "The Law of Interpretation," 130 Harvard Law Review 1079, 2017. -P.1083.

10. John Finnis, Introductionto Philosophy of law: Collected essays 1, 18 (2011).

11. William B \& Stephen E. Sachs, "The Law of Interpretation," 130 Harvard Law Review 1079, 2017. -P.1082.

12. Theoryofstateandlaw. MatuzovN.I., MalkoA.V. M .: Jurist, 2004 .- 512 p.

13. Theory of state and law. Textbook. Under the general editorship of prof. H.T.Odilkoriev. - T.: Sharq, 2009. -P.423.

14. Melekhin A.V. Theory of state and law: textbook. - M .: Market DS corporation, 2007.-P.381.

15. Michelle T. The problem of interpretation and the theory of the supremacy of the Constitution // Comparative constitutional review. M., 2005, P. 4-171. 
16. Arzamasov Yu.G. Problems of the doctrinal interpretation of law Vestnik RUDN, a series of Legal Sciences, 2016. -№ 4.

17. Hart H.L.A. The Concept of Law. 3rd edition. - Oxford: Oxford university press, 2012.- P.94.

18. Luttermann Karin. Ubersetzen juristisher Texte als ArbeiKlt'li» der Rechtslinguistik // tie Groot, Gerard-Rene; Schulze, Reiner ft" Recht und Ubersetzen. Baden-Baden: Nomos, 1999. -P. 47.

19. Bergel J.L. General theory of law. M., 2000. -P. 420.

20. Ilbert, The Mechanics of Law Making, Columbia University Press, 1914. -P.120.

21. Saidov A., Tojixonov U. Theory of state and law: Vol 2. Theory of law. - T.: Adolat, 2001. - P.227.

22. AdilkarievKh.T., TulteevI.T., N.P. Azizovandetc. Theory of state and law / Edited by Kh.T. Adilkariev. - T .: Academy of the Ministry of Internal Affairs of the Republic of Uzbekistan, 2014. - p.436.

23. Whittington K.E., Kelemen R.D., Caldeira G.A. Law and Politics. - New York: Oxford University Press, 2008. -P.361.

24. Whittington K.E., Kelemen R.D., Caldeira G.A. Law and Politics. - New York: Oxford University Press, 2008. -P.366.

25. Hart, JR., H.A., and Sacks, A.M. 1994. The Legal Process: Basic Problems in the Making and Application of Law, ed. W.N.Eskridge, JR. and P.P.Frickey. Westbury, NY: Foundation Press. -P.1378.

26. Whittington K.E., Kelemen R.D., Caldeira G.A. Law and Politics. - New York: Oxford University Press, 2008. -P.370.

27. Collection of legislation of the Republic of Uzbekistan, 2012, No. 52, Article 583; 2014, No. 50, Article 588; 2015, No. 32, Article 425; 2016, No. 39, Article 457.

28. Collection of legislation of the Republic of Uzbekistan, 2017, No. 22, Article 407, No. 37, Article 978. 